\title{
Physical attributes and limiting water range as soil quality indicators after mechanical harvesting of sugarcane
}

\author{
Oswaldo Julio Vischi Filho ${ }^{1}$, Zigomar Menezes de Souza ${ }^{1}$, Gustavo Soares de Souza ${ }^{2}$, Reginaldo \\ Barbosa da Silva ${ }^{3}$, José Luiz Rodrigues Torres ${ }^{4 *}$, Márcio Emanuel de Lima ${ }^{5}$, Rose Luiza Moraes \\ Tavares $^{1}$
}

\author{
${ }^{1}$ The State University of Campinas, Department of Water and Soil, Avenida Cândido Rondon, 501, Cidade \\ Universitária Zeferino Vaz, Barão Geraldo, CEP 13083-875 Campinas, SP, Brasil \\ ${ }^{2}$ INCAPER/CRDR-SC/FEBN, Rod, ES-483, km 2.5 - 29323-000 - Cachoeiro de Itapemirim, ES - Brazil \\ ${ }^{3}$ Paulista State University Júlio de Mesquita Filho, Department of Soils, Campus de Registro, Avenida Nelson \\ Brihi Badur, no 430, Vila Tupy, CEP 11900-000 Registro, SP, Brazil \\ ${ }^{4}$ Federal Institute of Triângulo Mineiro (IFTM) Campus Uberaba, Professor, Doctor of Plant Production, Rua \\ João Batista Ribeiro, 4000, CEP 39064-790, Brazil \\ ${ }^{5}$ Department of Agriculture and Supply of the State of São Paulo, Coordinator of Agricultural Defense, Avenida \\ Brasil, no 2.340, CEP 13070-178 Campinas, SP, Brazil
}

*Corresponding author: jlrtorres@iftm.edu.br

\begin{abstract}
Monitoring soil physical quality in areas cultivated with sugarcane has become a key management practice of this crop. It is due to the in-field traffic of heavy machines, implements, high mass harvesters and transhipments in the area have caused changes in soil structure and promoted the fall of the crop yield.. This study evaluated physical attributes of soil and the least limiting water range to assess the effects caused by wheel traffic in areas with mechanized harvest of sugarcane. The design was completely randomized in a factorial $2 \times 2 \times 4$, which were evaluated two areas of mechanical harvesting: 1 - Six years $\left(T_{1}\right) ; 2$ - Eighteen years of cultivation $\left(\mathrm{T}_{2}\right)$; Two sampling sites: 1 - Canteiro; 2 - Planting line; Four layers of soil sampled (0.00 to 0.10, 0.10-0.20, 0.20-0.30 and 0.30-0.40 $\mathrm{m})$ with 4 repetitions. We evaluated bulk density (BD), mechanical resistance to penetration (RP), water content in the soil (WCS), macroporosity (Ma), microporosity (Mi), total porosity (TP), water retention curve, the least limiting water range (LLWR) and soil organic carbon (SOC). We observed that the area with mechanical harvest system after three crop cycles produced a high loadbearing capacity and high SOC. The same area also demonstrated high Ma and LLWR, and low BD and RP levels in the rows. The LLWR levels were high as well in the area with one cane cycle but decreased as the number of harvest cycles increased. In the areas with one and three cycles the critical bulk density (CBD) ranged between 1.40-1.50 $\mathrm{Mg} \mathrm{m}^{-3}$ and 1.24-1.28 $\mathrm{Mg} \mathrm{m}^{-3}$ respectively, while the LLWR was zero (LLWR =0) with the limiting RP between 2.0 and $3.5 \mathrm{Mpa}$. The physical attributes are changed by heavy machinery traffic in the cane fields, but the effects of these changes are minimized when several crop cycles are conducted in the same area.
\end{abstract}

Keywords: compaction, soil porosity, mechanization, the least limiting water range.

Abbreviations: BD_Bulk Density, RP_Mechanical resistance to penetration, WCS _ Water content in the soil, Ma _ Macroporosity, $\mathrm{Mi} \_$Microporosity, TP _ Total porosity, WRC _ Water retention curve, LLWR_the least limiting water range, SOC _ Soil organic carbon.

\section{Introduction}

Brazil is the world's largest producer of sugarcane destined for sugar and ethanol. The state of São Paulo ranks first place on the national scene occupying $51.8 \%$ of the total area (4.648.200.000 hectares) planted in 2015/2016, with estimated production of 348.36 million tons and an average yield of $74.945 \mathrm{~kg} \mathrm{ha}^{-1}$ (Conab, 2015). The management of areas cultivated with sugarcane is based on deep soil mixing with heavy machinery during the preparation and planting. To this, one must add repeated in-field traffic of harvesters and haulaut vehicles with weight ranging from 20 to 30 tons for several crop cycles, thereby causing changes in soil physical properties (Torres et al., 2013). These changes influence macroporosity, aggregate size, water infiltration rates, bulk density (BD) and resistance to penetration (RP) (Camargo et al., 2010), which in turn decrease the yield of the crop. According to Mosaddeghi et al. (2007) soil compression is as a major cause of land degradation, as it negatively influences all other physical attributes. Ways to determine the load-bearing capacity of the soil are necessary as the intense traffic of heavy machinery will continue, as well as the impact of these practices on soil physical properties (Campos et al., 2015). Souza et al. (2014) emphasize that the quantification of soil resistance to the applied loads is essential to calculate the permeability and define regions of greater or lesser susceptibility to 
compaction. Together with the density and porosity they are considered good indicators of soil quality.

To monitor the physical quality of the soil, Silva et al. (1994) and Tormena et al. (1998) used the least limiting water range (LLWR) as an indicator of structural quality. The same authors also pointed out that the LLWR is directly related to crop productivity, and that it integrates the matric potential, aeration and RP in a single attribute helping to establish soil moisture conditions limiting plant growth which occur between the upper and the lower limits of LLWR.

Some studies have shown that decreasing LLWR values increase bulk density. These changes have a negative impact on plant growth by hindering root development due to water restrictions in soil (Smith et al., 2015). Safadoust et al. (2014) emphasize that the LLWR may also increase with increasing bulk density to values ranging between 1.42 and $1.60 \mathrm{Mg} \mathrm{m}^{-3}$ in sandy soils, which then fall sharply. Guimaraes et al. (2013) found a critical density of $1.80 \mathrm{Mg} \mathrm{m}^{-3}$ at which the aeration porosity did not limit the evaluated soils, and that this value decreased with increasing BD. Chen et al. (2014) and Mishra et al. (2015) observed that the use of different cover crops in rotation with cash crops and the maintenance of organic residues on the soil surface increased LLWR and reduced limitations caused by unfavorable $\mathrm{BD}$ and RP.

Assessing in-field controlled traffic system in Oxisol under sugarcane, Roque et al. (2011) found that RP values increased with increasing soil density, and that to maintain $\mathrm{RP}$ at 2.0 MPa it was necessary to increase soil water content. They found critical densities at $1.17,1.18$ and $1.11 \mathrm{Mg} \mathrm{m}^{-3}$ for the treatments with automatic steering, controlled traffic and the control, respectively. In all treatments the LLWR had $\mathrm{RP}$ as the lower limiting point. In a similar study on the same soil Araújo et al. (2013) observed critical density at $1.39 \mathrm{Mg}$ $\mathrm{m}^{-3}$ with null LLWR.

This study aimed to evaluate soil physical attributes and the least limiting water range, and to relate them to the effects caused by the in-field wheel traffic on sugarcane plantations with mechanized harvest.

\section{Results and Discussion}

\section{The indicators of soil compaction}

\section{Resistance to penetration (RP) and soil bulk density (BD)}

Analyzing the soil physical attributes we observed significant management/sampling site and management/soil layer interactions for all attributes except for macroporosity (Table 1). Regarding soil density (BD), we observed that the obtained values in both treatments $\left(T_{1}\right.$ and $\left.T_{2}\right)$ were lower for the row comparing with the near-row, which ranged from $1.32-1.50 \mathrm{Mg} \mathrm{m}^{-3}$ to $1.35-1.56 \mathrm{Mg} \mathrm{m}^{-3}$, respectively. The lowest $\mathrm{BD}$ values for the row and near-row seedbed were found in the area with three production cycles $\left(\mathrm{T}_{2}\right)$ comparing with the area with one production cycle $\left(\mathrm{T}_{1}\right)$ (Table 2 ). Smaller BD values in $\mathrm{T}_{2}$ were due to stubble mulching and subsequent subsoiling and harrowing performed after each cycle, thereby altering the soil structure. Another important factor in this area is the accumulation of cane trash on soil surface, which annually accumulates more than $13 \mathrm{Mg} \mathrm{ha}^{-1}$ of straw. This trash blanket dissipates the force applied by wheels and minimizes the effects of the machines on compression. This blanket also increases the soil organic carbon content which strengthens the aggregation of soil particles.
The results of this study were similar to those reported by Neves et al. (2003) who, evaluating areas with compacted and undergoing compaction clayey Oxisol, obtained BD values of $1.42 \mathrm{Mg} \mathrm{m}^{-3}$ in the area with already compacted soil and $1.33 \mathrm{Mg} \mathrm{m}^{-3}$ in the area with soil undergoing compaction process. Severiano et al. (2009), who studied the structural quality of a Red-Yellow Latosol under sugarcane, found BD values of $1.28 \mathrm{Mg} \mathrm{m}^{-3}$ in the $0.00-0.05 \mathrm{~m}$ layer and $1.36 \mathrm{mg}$ $\mathrm{m}^{-3}$ in the $0.30-0.40 \mathrm{~m}$ layer. However, BD values found in our study were higher than $1.26 \mathrm{Mg} \mathrm{m}^{-3}$ obtained by Souza et al. (2015) who evaluated the cultivation of sugarcane with controlled traffic on Oxisol.

Analyzing the data of soil resistance to penetration (RP) we observed no difference between the systems with $T_{1}$ and $T_{2}$ when the samples were taken from the near-row strips $(\mathrm{S})$. However, the same did not occur when the samples were taken from the rows $(\mathrm{R})$. The highest RP was observed in the treatment with one production cycle (3.12 MPa), while in the $\mathrm{T}_{2}$ treatment the mean value was $2.73 \mathrm{MPa}$ (Table 3 ). It indicates that the higher RP value for the near-row seedbed may be due to soil compaction caused by wheel traffic of machines used to perform operations in the fields, as the wheel path is closer to the near-row strip than the planting row. With the use of the controlled traffic system the influence of wheel traffic on the crop row is minimized.

The results corroborate those obtained by Cavichiolli et al. (2012), who noted that the average RP down to $0.40 \mathrm{~m}$ of depth was higher for the near-row strips of sugarcane relative to the rows due to the wheel traffic in the center of the interrows causing changes in the soil profile, thus affecting mean values of RP. Braunack et al. (2006) observed changes in the soil caused by wheel traffic in cane fields down to $0.30 \mathrm{~m}$ deep.

Harvest and haulout systems used in the management of sugarcane: increase bulk density (BD), resistance to penetration (RP) and microporosity (Mi); decrease macroporosity (Ma); reduce water infiltration; and change the size and shape of the aggregates, consequently decreasing the yield of the crop (Materechera, 2009; Camargo et al., 2010). Gorucu et al. (2006) also observed higher BD and lower RP in the subsurface layers than in the layers above or below them, with variability in depth and thickness.

\section{Macroporosity (Ma), microporosity (Mi) and total porosity (TP)}

There were no differences $(\mathrm{p} \leq 0.05)$ among the treatments regarding macroporosity $(\mathrm{Ma})$, which can be explained by the fact that the sugarcane mill uses in-field controlled traffic. This system helps preserve the near-row strips and the rows against traffic-induced compaction. The values of $\mathrm{Ma}$ remained below $0.10 \mathrm{~m}^{3} \mathrm{~m}^{-3}$ (Table 2), which, according to Kopi and Douglas (1991), is the minimum for the macropores to exchange gases necessary for the development of the root system.

The microporosity (Mi) was affected in the evaluated systems. The values in the 3-cycle area were always higher than in the 1-cycle treatment. However, there were no differences among the studied layers. Similar results were observed by Souza et al. (2014), who found no effect of treatments on Mi on the sampling sites, as the micropores remained virtually unchanged indicating low effect of compression on this attribute. According to Silva and Kay (1997) soil Mi is strongly influenced by the texture and the organic carbon content and very little influenced by the 
Table 1. Coefficients of linearized equations for resistance to penetration as a function of water content and bulk density [ln RP $=\ln$ $\mathrm{a}+\mathrm{b} \ln \theta+\mathrm{c} \ln \mathrm{BD}]\left(\mathrm{R}^{2}=0.62\right.$ and 0.88$)$ and for the water content as a function of density and matric potential $[\ln \theta=\mathrm{d}+\mathrm{e} B \mathrm{BD}+\mathrm{f}$ $\ln \Psi]\left(\mathrm{R}^{2}=0.62\right.$ e 0.63$)$ of soil for managements with one (T1) and three cycles (T2) with mechanical harvest.

\begin{tabular}{|c|c|c|c|c|}
\hline Parameter & Value & Standard error & $\mathrm{t}$ & Probability \\
\hline \multicolumn{5}{|l|}{$\mathrm{T} 1$} \\
\hline$a^{(1)}$ & -4.1228 & 0.4314 & -9.56 & $<0.0001$ \\
\hline B & -2.5404 & 0.2507 & -10.13 & $<0.0001$ \\
\hline $\mathrm{C}$ & 5.9322 & 0.5613 & 10.57 & $<0.0001$ \\
\hline D & -1.9238 & 0.1905 & -10.10 & $<0.0001$ \\
\hline $\mathrm{E}$ & -0.0526 & 0.0065 & -8.12 & $<0.0001$ \\
\hline $\mathrm{F}$ & 0.6214 & 0.1278 & 4.86 & $<0.0001$ \\
\hline \multicolumn{5}{|l|}{$\mathrm{T} 2$} \\
\hline A & -4.1401 & 0.2840 & -14.58 & $<0.0001$ \\
\hline B & -3.6884 & 0.2235 & -16.50 & $<0.0001$ \\
\hline $\mathrm{C}$ & 6.4230 & 0.5704 & 11.26 & $<0.0001$ \\
\hline D & -1.4353 & 0.1997 & -7.19 & $<0.0001$ \\
\hline $\mathrm{E}$ & -0.0541 & 0.0053 & -10.20 & $<0.0001$ \\
\hline $\mathrm{f}$ & 0.4873 & 0.1530 & 3.18 & $<0.0001$ \\
\hline
\end{tabular}
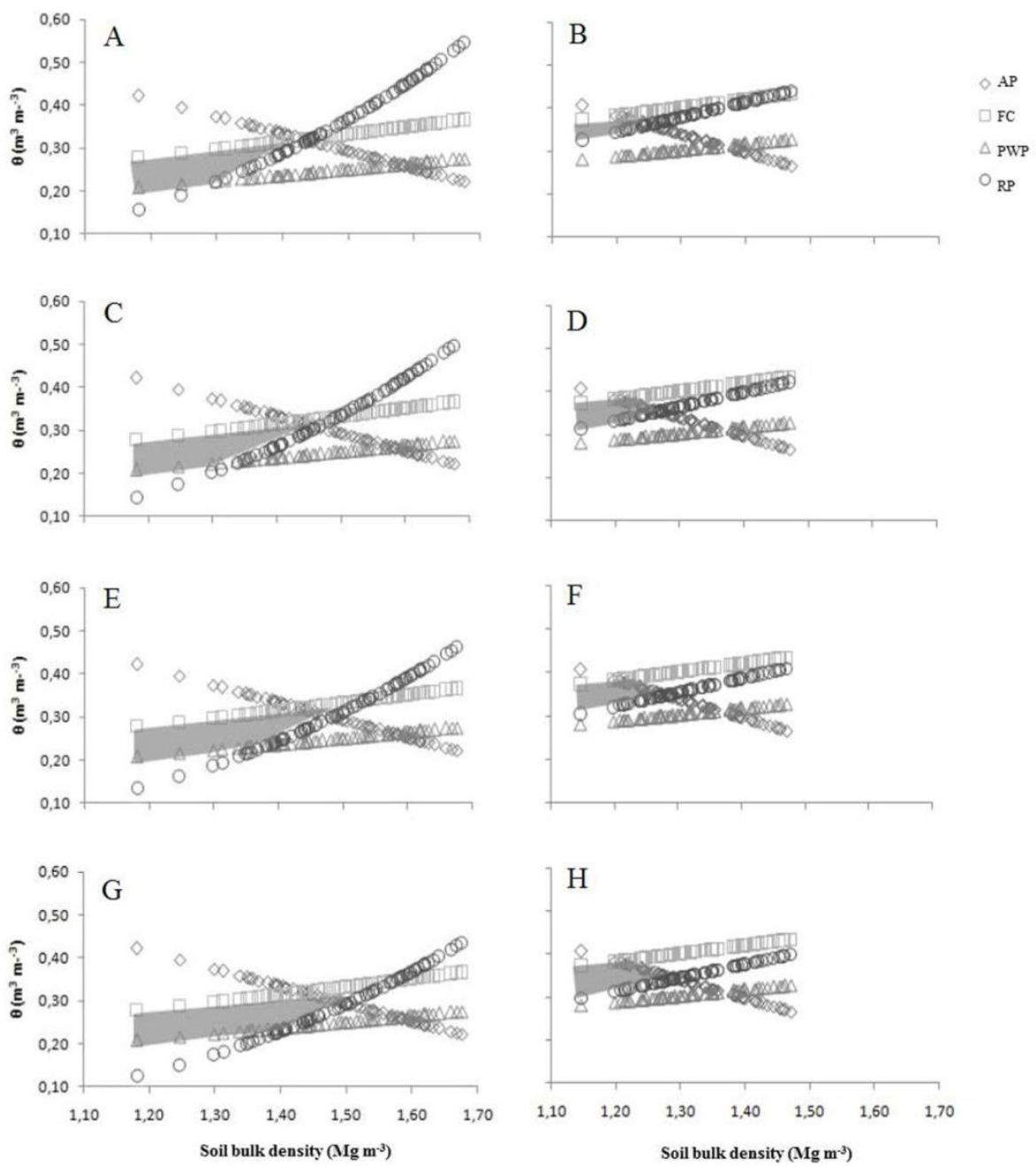

Fig 1. Water content in the soil at: field capacity $\left(\theta_{\mathrm{FC}}=-0.01 \mathrm{MPa}\right)$, permanent wilting point $\left(\theta_{\mathrm{PWP}}=-1.5 \mathrm{MPa}\right)$, aeration porosity $\left(\theta_{\mathrm{AP}}=0,10 \mathrm{~m}^{3} \mathrm{~m}^{-3}\right)$ with soil resistance to penetration $\left[\theta_{\mathrm{RP}}=2.0(\mathrm{~A}, \mathrm{~B}) ; 2.5(\mathrm{C}, \mathrm{D}) ; 3.0(\mathrm{E}, \mathrm{F})\right.$ and $3.5(\mathrm{G}, \mathrm{H}) \mathrm{MPa}$ ]. The least limiting water range after one $(\mathrm{A}, \mathrm{C}, \mathrm{E}, \mathrm{G})$ and three $(\mathrm{B}, \mathrm{D}, \mathrm{F}, \mathrm{H})$ sugarcane crop cycles. 
Table 2. Physical attributes of soil in the planting row (R) and near-row seedbed (S), and in the evaluated layers in managements with one $\left(T_{1}\right)$ and three cycles $\left(T_{2}\right)$ with mechanical harvest, during the safra 2012/13.

\begin{tabular}{|c|c|c|c|c|c|c|c|}
\hline \multirow[t]{2}{*}{ Treatment } & \multicolumn{2}{|l|}{ Sampling } & \multicolumn{4}{|l|}{ Soil layer } & \multirow[t]{2}{*}{ Mean } \\
\hline & $\mathrm{R}$ & $\mathrm{S}$ & $0.00-0.10$ & $0.10-0.20$ & $0.20-0.30$ & $0.30-0.40$ & \\
\hline \multicolumn{8}{|l|}{$\mathrm{BD}\left(\mathrm{Mg} \mathrm{m}^{-3}\right)$} \\
\hline $\mathrm{T}_{1}$ & $1.50 \mathrm{Ab}$ & $1.56 \mathrm{Aa}$ & $1.53 \mathrm{Aa}$ & $1.52 \mathrm{Aa}$ & $1.52 \mathrm{Aa}$ & $1.54 \mathrm{Aa}$ & 1.53 \\
\hline $\mathrm{T}_{2}$ & $1.32 \mathrm{Ba}$ & $1.35 \mathrm{Ba}$ & $1.30 \mathrm{Ba}$ & $1.33 \mathrm{Ba}$ & $1.34 \mathrm{Ba}$ & $1.39 \mathrm{Aa}$ & 1.34 \\
\hline Mean & 1.41 & 1.46 & 1.42 & 1.43 & 1.44 & 1.46 & \\
\hline $\mathrm{CV}(\%)$ & 5.11 & & & & & & \\
\hline \multicolumn{8}{|l|}{$\mathrm{TP}\left(\mathrm{m}^{3} \mathrm{~m}^{-3}\right)$} \\
\hline $\mathrm{T}_{1}$ & $0.45 \mathrm{Ba}$ & $0.44 \mathrm{Ba}$ & $0.47 \mathrm{Ba}$ & $0.43 \mathrm{Ba}$ & $0.43 \mathrm{Ba}$ & $0.44 \mathrm{Ba}$ & 0.44 \\
\hline $\mathrm{T}_{2}$ & $0.50 \mathrm{Aa}$ & $0.50 \mathrm{Aa}$ & $0.52 \mathrm{Aa}$ & $0.50 \mathrm{Aa}$ & $0.49 \mathrm{Aa}$ & $0.50 \mathrm{Aa}$ & 0.50 \\
\hline Mean & 0.48 & 0.47 & 0.50 & 0.47 & 0.46 & 0.47 & \\
\hline $\mathrm{CV}(\%)$ & 8.79 & & & & & & \\
\hline \multicolumn{8}{|l|}{$\mathrm{Ma}\left(\mathrm{m}^{3} \mathrm{~m}^{-3}\right)$} \\
\hline $\mathrm{T}_{1}$ & 0.10 & 0.08 & 0.09 & 0.08 & 0.09 & 0.10 & $0.09 \mathrm{~A}$ \\
\hline $\mathrm{T}_{2}$ & 0.08 & 0.08 & 0.07 & 0.08 & 0.08 & 0.08 & $0.08 \mathrm{~A}$ \\
\hline Mean & $0.09 \mathrm{a}$ & $0.08 \mathrm{a}$ & $0.08 \mathrm{a}$ & $0.08 \mathrm{a}$ & $0.09 \mathrm{a}$ & $0.09 \mathrm{a}$ & \\
\hline $\mathrm{CV}(\%)$ & 15.18 & & & & & & \\
\hline \multicolumn{8}{|l|}{$\operatorname{Mi~}\left(\mathrm{m}^{3} \mathrm{~m}^{-3}\right)$} \\
\hline $\mathrm{T}_{1}$ & $0.34 \mathrm{Ba}$ & $0.36 \mathrm{Ba}$ & $0.38 \mathrm{Ba}$ & $0.34 \mathrm{Ba}$ & $0.34 \mathrm{Ba}$ & $0.34 \mathrm{Ba}$ & 0.35 \\
\hline $\mathrm{T}_{2}$ & $0.42 \mathrm{Aa}$ & $0.43 \mathrm{Aa}$ & $0.45 \mathrm{Aa}$ & $0.42 \mathrm{Aa}$ & $0.41 \mathrm{Ab}$ & $0.41 \mathrm{Aa}$ & 0.42 \\
\hline Mean & 0.38 & 0.39 & 0.4 & 0.38 & 0.38 & 1.83 & \\
\hline $\mathrm{CV}(\%)$ & 5.93 & & & & & & \\
\hline \multicolumn{8}{|l|}{$\mathrm{OC}\left(\mathrm{g} \mathrm{kg}^{-1}\right)$} \\
\hline $\mathrm{T}_{1}$ & $2.12 \mathrm{Ba}$ & $2.02 \mathrm{Bb}$ & $2.45 \mathrm{Ba}$ & $2.16 \mathrm{Bb}$ & $1.91 \mathrm{Ac}$ & $1.75 \mathrm{Ac}$ & 2.07 \\
\hline $\mathrm{T}_{2}$ & $2.67 \mathrm{Aa}$ & $2.39 \mathrm{Ab}$ & $3.44 \mathrm{Aa}$ & $2.73 \mathrm{Ab}$ & $2.06 \mathrm{Ac}$ & $1.91 \mathrm{Ac}$ & 2.54 \\
\hline Mean & 2.40 & 2.21 & 2.95 & 2.45 & 1.99 & 1.83 & \\
\hline $\mathrm{CV}(\%)$ & 5.93 & & & & & & \\
\hline
\end{tabular}

*Means followed by the same upper case letter in the column and lower case in the line do not differ statistically by Tukey test at $5 \%$ probability. BD = soil bulk density; $\mathrm{TP}=$ total porosity; $\mathrm{Ma}=$ Macroporosity; $\mathrm{Mi}=$ Microporosity; $\mathrm{OC}=$ organic carbon.
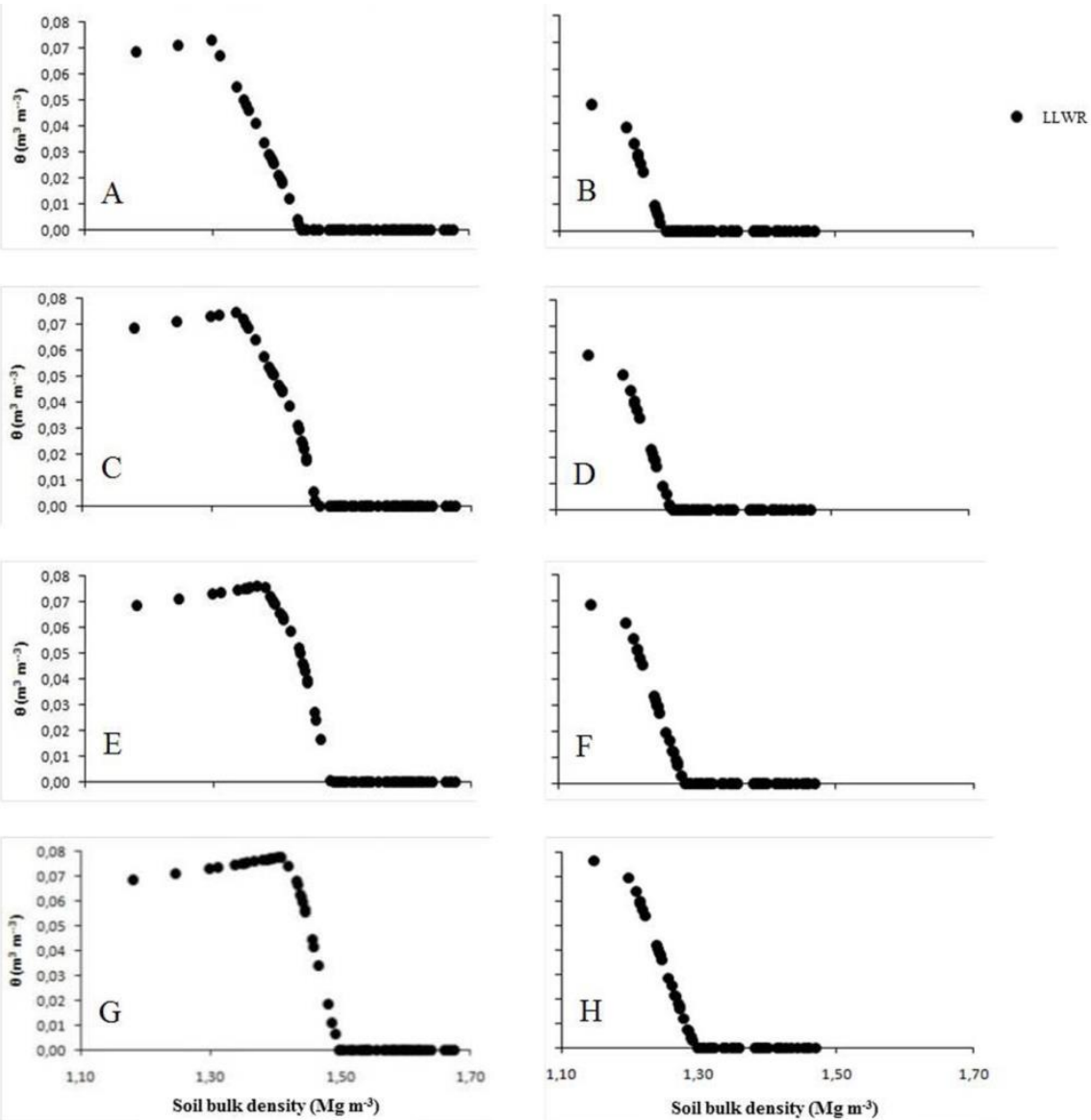

Fig 2. The least limiting water range in soil after one (A, C, E, G) and three (B, D, F, H) sugarcane crop cycles, considering the limiting resistance to soil penetration at $2.0(\mathrm{~A}, \mathrm{~B}) ; 2.5(\mathrm{C}, \mathrm{D}) ; 3.0(\mathrm{E}, \mathrm{F}) ; 3.5(\mathrm{G}, \mathrm{H}) \mathrm{MPa}$. 
Table 3. Soil resistance to penetration (RP) and water content in the soil (WCS) determined in the planting row (R), near-row seedbed $(\mathrm{S})$, and in the layers of $0.00-0.10,0.10-0.20,0.20-0.30$ and $0.30-0.40 \mathrm{~m}$ on areas with mechanized harvest system with 1 and 3 sugarcane crop cycles.

\begin{tabular}{|c|c|c|c|c|c|c|c|}
\hline \multirow[t]{2}{*}{ Treatment } & \multicolumn{2}{|l|}{ Sampling } & \multicolumn{4}{|l|}{ Soil layer } & \multirow[t]{2}{*}{ Mean } \\
\hline & $\mathrm{R}$ & IR & $0.00-0.10$ & $0.10-0,20$ & $0.20-0.30$ & $0.30-0.40$ & \\
\hline \multicolumn{8}{|l|}{$\operatorname{RP}\left(\mathrm{MPa}^{3}\right)$} \\
\hline $\mathrm{T}_{1}$ & $3.12 \mathrm{Ab}$ & $3.44 \mathrm{Aa}$ & $4.58 \mathrm{Aa}$ & $2.98 \mathrm{Bb}$ & $3.59 \mathrm{Bb}$ & $2.28 \mathrm{Cc}$ & $3.28 \mathrm{~A}$ \\
\hline $\mathrm{T}_{2}$ & $2.73 \mathrm{Bb}$ & $3.23 \mathrm{Aa}$ & $4.78 \mathrm{Aa}$ & $2.63 \mathrm{Bb}$ & $2.21 \mathrm{Cc}$ & $2.28 \mathrm{Cc}$ & $2.98 \mathrm{~B}$ \\
\hline Mean & 2.93 & 3.34 & $4.68 \mathrm{a}$ & $2.81 \mathrm{~b}$ & $2.75 \mathrm{~b}$ & $2.28 \mathrm{c}$ & \\
\hline $\mathrm{CV}(\%)$ & 9.95 & & & & & & \\
\hline \multicolumn{8}{|c|}{ WCS $\left(\mathrm{kg} \mathrm{kg}^{-1}\right)$} \\
\hline $\mathrm{T}_{1}$ & $0.17 \mathrm{Ba}$ & $0.18 \mathrm{Ba}$ & $0.19 \mathrm{Ba}$ & $0.17 \mathrm{Ba}$ & $0.18 \mathrm{Ba}$ & $0.18 \mathrm{Ba}$ & $0.18 \mathrm{~B}$ \\
\hline $\mathrm{T}_{2}$ & $0.30 \mathrm{Aa}$ & $0.32 \mathrm{Aa}$ & $0.32 \mathrm{Aa}$ & $0.32 \mathrm{Aa}$ & $0.30 \mathrm{Aa}$ & $0.29 \mathrm{Aa}$ & $0.31 \mathrm{~A}$ \\
\hline Mean & 0.23 & 0.25 & $0.26 \mathrm{a}$ & $0.25 \mathrm{ab}$ & $0.24 \mathrm{ab}$ & $0.23 b$ & \\
\hline $\mathrm{CV}(\%)$ & 6.47 & & & & & & \\
\hline
\end{tabular}

increased soil density caused by machinery, implements and others. Total porosity (TP) did not show significant interactions among the areas and the sampling sites, however the highest value of $\mathrm{TP}$ was observed in the $\mathrm{T}_{2}$ treatment $\left(0.50 \mathrm{~m}^{3} \mathrm{~m}^{-3}\right)$ in the near-row seedbed and in the row, while in the $\mathrm{T}_{1}$ treatment the highest value was $0.45 \mathrm{~m}^{3} \mathrm{~m}^{-3}$ in the row (Table 2). The TP values in the area with $\mathrm{T}_{2}$ were always higher $(\mathrm{p} \leq 0.05)$ than the values in the area with $\mathrm{T}_{1}$ in the row, in the near-row seedbed and in the evaluated layers, which suggests that more sugarcane cycles increase TP. This fact is directly related to soil tillage after each harvest, straw accumulation on the surface and the residue left by the root system of sugarcane, which after each replanting decompose increasing soil TP. The results of TP were similar to those reported by Neves et al. (2003) who studied different uses, managements and total porosity of compacted and undergoing compaction soils, and found 0.49 and $0.52 \mathrm{~m}^{3} \mathrm{~m}^{-}$ ${ }^{3}$, respectively. However, the values were lower than 0.60 $\mathrm{m}^{3} \mathrm{~m}^{-3}$ obtained for the uncompressed soil. Souza et al. (2014), who studied the effect of controlled wheel traffic of on soil physical quality in sugarcane, found no effect of treatments on TP values, while Souza et al. (2005) found TP values close to $0.50 \mathrm{~m}^{3} \mathrm{~m}^{-3}$ in a study with sugarcane after the fifth harvest.

\section{Soil organic carbon}

The organic carbon content in the row was higher relative to the content in the near-row seedbed with the highest values found in the $\mathrm{T}_{2}$ system (Table 2). It can be explained by higher concentration of roots in the row which increase carbon content. As for the sampled layers, carbon levels were higher in the layer of $0.00-0.10 \mathrm{~m}$, decreasing at greater depths. It shows a strong influence of the residues left by the root system of the crop on this parameter, because in this system $75 \%$ or more of the roots are concentrated down to $0.40 \mathrm{~m}$ deep (Vezzani and Mielniczuk, 2011; Souza et al, 2014). Fertilization with filter cake in the rows also influenced the levels of organic carbon. Evaluating mechanical harvest of sugarcane in Oxisol under all management cycles, Souza et al. (2012) found higher carbon content in the topsoil layer and gradual reduction of its levels in deeper layers due to the use of the cultivator which promoted the incorporation of plant debris into the $0.00-0.10$ m soil layer.

\section{The water retention curve in the soil}

Assessing the water retention curve in the soil we observed that there was no difference $(\mathrm{p} \leq 0.05)$ regarding the available water capacity (AWC) in the 0.00-0.10 m layer. However, there was an increase by $2.3 \%$ in the $0.10-0.20 \mathrm{~m}$ layer in the row in area with $\mathrm{T}_{2}$ over the area with $\mathrm{T}_{1}$. In the $0.20-0.30 \mathrm{~m}$ layer in the near-row strips AWC was higher in the area with $\mathrm{T}_{2}$. The system with 3 cycles had higher AWC in the layer of $0.30-0.40 \mathrm{~m}$, both in the near-row strips and in the rows, with values above $4.2 \%$ for the rows and $2.6 \%$ for the near-rows. These results are similar to those obtained by Smith et al. (2008), who studying sugarcane under Dystrophic Red Latosol and Eutroferric Red Latosol, found increasing water retention in soils with higher clay content $(48.07 \%)$ when the water content was $0.40 \mathrm{~m}^{3} \mathrm{~m}^{-3}$ and AWC was $0.10 \mathrm{~m}^{3} \mathrm{~m}^{-3}$.

No significant difference ( $\mathrm{p} \leq 0.05$ ) was observed among sampling sites and layers regarding the water retention curves and RP. The models tested for RP depending on the BD and WCS in treatments with $\mathrm{T}_{1}$ and $\mathrm{T}_{2}$ explained $62 \%$ and $88 \%$ of the variability of the data, respectively. The RP was correlated positively with BD and negatively with the WCS $(\square)$ for treatments with $T_{1}$ and $T_{2}$, corroborating Tormena et al. (1998), Leo et al. (2006) and Silva et al. (2011). The coefficients presented in Table 1 for mechanized harvest with $\mathrm{T}_{1}$ and $\mathrm{T}_{2}$ are used to represent the RP curve, according to equations 1 and 2 .

$\mathrm{RP}_{\mathrm{T} 1}=0.0162 * \theta^{-2.5404 *} \mathrm{BD}^{5.9322}$

$\mathrm{RP}_{\mathrm{T} 2}=0.0159 * \theta^{-3.6884} * \mathrm{BD}^{6.4230}$

\section{The least limiting water range (LLWR)}

We estimated the water content potential at $-0.01 \mathrm{MPa}\left(\theta_{\mathrm{FC}}=\right.$ field capacity) and $-1.5 \mathrm{MPa}\left(\theta_{\mathrm{PWP}}=\right.$ permanent wilting point). These values are necessary to determine the LLWR using the coefficients in table 1 to compose the equations 3 , 4,5 and 6.

$\theta_{\mathrm{T} 1}=\exp ^{(-1.9238-0.0526 * \mathrm{BD})} * 0.01^{0.6214}$

$\theta_{\mathrm{T} 1}=\exp ^{(-1.9238-0.0526 * \mathrm{BD})} * 1.5^{0,6214}$

$\theta_{\mathrm{T} 2}=\exp ^{(-1.4353-0,0541 * \mathrm{BD}) * 0.01^{0.4873}}$

$\theta_{\mathrm{T} 2}=\exp ^{(-1.4353-0,0541 * \mathrm{BD})} * 1.5^{0.4873}$

Higher BD increased WCS at field capacity and permanent wilting point (Figure 1) in both treatments. For mechanized harvest with $\mathrm{T}_{1}$, the upper limit was set by $\theta_{\mathrm{FC}}$ for $\mathrm{BD} \leq 1.40$ $\mathrm{Mg} \mathrm{m}{ }^{-3}$, and thereafter replaced by $\theta_{\mathrm{AP}}$. This behavior occurred regardless of limiting RP (Figure 1A, C, E, G). For limiting RP of $2.0 ; 2.5 ; 3.0$ and $3.5 \mathrm{MPa}$, the $\theta_{\mathrm{PWP}}$ was the lower limit of LLWR for BD $\leq 1.30 ; 1.31 ; 1.37$ and $1.40 \mathrm{Mg}$ $\mathrm{m}^{-3}$, respectively, and thereafter replaced by $\theta_{\mathrm{RP}}$. For mechanized harvest with 3 cycles, the upper limit was set by $\theta_{\mathrm{FC}}$ for $\mathrm{BD} \leq 1.20 \mathrm{Mg} \mathrm{m}^{-3}$, and thereafter replaced by $\theta_{\mathrm{AP}}$ (Figure 1B, D, F, H), which was also independent of limiting RP. For mechanized harvest with three cycles, the $\theta_{\mathrm{RP}}$ was 
the lower limit of LLWR regardless of soil density value and limiting RP.

For the treatment with 1 cycle the critical bulk density of the soil (CBD), with LLWR=0, was respectively $1.40 ; 1.44$; 1.47 and $1.50 \mathrm{Mg} \mathrm{m}^{-3}$ for a limiting RP of $2.0 ; 2.5 ; 3.0$ and $3.5 \mathrm{MPa}$, while for treatment with three cycles the CBD was 1.24; $1.26 ; 1.27$ and $1.28 \mathrm{Mg} \mathrm{m}^{-3}$ (Figures 1 and 2). These results are similar to those found by Araújo et al. (2013) who studied harvesting systems and LLWR in Oxisol under sugarcane on areas with mechanized harvest and found CBD $=1.39 \mathrm{Mg} \mathrm{m}^{-3}$ for LLWR $=0$.

The CBD values were higher when compared to the results observed by Moreira et al. (2012) who evaluated LLWR in an Oxisol. These authors found that the intersection of LLWR was determined by $\theta_{\mathrm{FC}}$ and $\theta_{\mathrm{RP}}$ with CBD lower than 1.30 . These values were lower than those observed by Imhoff et al. (2001) who studied the critical restrictions for the growth of plants and found CBD of $1.70 \mathrm{Mg} \mathrm{m}^{-3}$, the intersection where the LLWR is zero between $\theta_{\mathrm{FC}}$ and $\theta_{\mathrm{RP}}$.

The $\theta_{\mathrm{AP}}$ decreased with higher $\mathrm{BD}$ in both treatments and RP limiting values. The $\theta_{\mathrm{AP}}$ in T1 was higher than $\theta_{\mathrm{FC}}$ for $\mathrm{BD}$ $\leq 1,40 \mathrm{Mg} \mathrm{m}^{-3}$, indicating no restriction for roots due to the lack of aeration. This behavior differs from $\mathrm{T}_{2}$ since the $\theta_{\mathrm{AP}}$ was lower than $\theta_{\mathrm{FC}}$ for $\mathrm{BD}>1.20 \mathrm{Mg} \mathrm{m}^{-3}$, reducing the LLWR at lower density, indicating a greater change in soil structure due to the higher number of crop cycles with mechanized harvests. Guimarães et al. (2013) studied the connection between LLWR and the physical degradation of dystrophic Oxisols and observed that the porosity decreased with increasing density, but did not limit the soils. The aeration porosity was lower than the field capacity at density values greater than $1.80 \mathrm{Mg} \mathrm{m}^{-3}$. Mishra et al. (2015) observed that maintaining the residues on the surface of the soil lowered BD and RP values in layer $0.0-0.15 \mathrm{~m}$,

For T1 the amplitude of the LLWR was from 0.00 to 0.08 $\mathrm{m}^{3} \mathrm{~m}^{-3}$ (Figure 2A, C, E, G). These values are higher than the results found by Imhoff et al. (2001), which were 0 to 0.05 $\mathrm{m}^{3} \mathrm{~m}^{-3}$, and lower than the values found by Silva et al. (1994) for a medium textured hydromorphic soil which varied from $0-0.14 \mathrm{~m}^{3} \mathrm{~m}^{-3}$ for $\mathrm{BD}=1.36 \mathrm{Mg} \mathrm{m}^{-3}$ to $0.05-0.13 \mathrm{~m}^{3} \mathrm{~m}^{-3}$ for $\mathrm{BD}=1.43 \mathrm{Mg} \mathrm{m}^{-3}$, and for limiting RP of $2.0 \mathrm{MPa}$.

For the mechanized harvest system with $\mathrm{T}_{2}$ the least limiting water range (LLWR) varied from 0.000 to $0.075 \mathrm{~m}^{3} \mathrm{~m}^{-3}$ (Figure 1B, D, F, H). These values are similar to those found by Guimarães et al. (2013) who used the LLWR to assess physical degradation of an Oxisol under native forest, pasture, citrus and annual crops, and found LLWR variations between 0.00 and $0.070 \mathrm{~m}^{3} \mathrm{~m}^{-3}$.

\section{Materials and Methods}

\section{Description of the experimental area}

\section{Site description}

The experiment was carried out on sugarcane (Saccharum sp.) commercial plantations which belong to the Usina São Martinho, located at $21^{\circ} 19^{\prime} 13.7^{\prime \prime} \mathrm{S}$ and $48^{\circ} 07^{\prime} 14.0^{\prime \prime} \mathrm{W}$, in the municipality in Pradópolis-SP, during safra 2012/2013.

\section{Soil type}

Two experimental areas were used. The first area with one crop cycle (six years) and soil characterized as Eutrophic Yellow Latosol (EYL) (Embrapa, 2013), clayey, with softwavy relief, was located at the coordinates of $21^{\circ} 19^{\prime} 33.0^{\prime \prime} \mathrm{S}$ and $48^{\circ} 066^{\prime} 53.6^{\prime \prime} \mathrm{W}$, and an altitude of $531 \mathrm{~m}$. The second area with three crop cycles (18 years), and the soil characterized as Eutroferric Red Latosol (EfRL), clayey, with soft-wavy relief, was located at the coordinates of $21^{\circ} 18 ' 20.0^{\prime \prime S}$ and $48^{\circ} 08^{\prime} 03.6^{\prime \prime} \mathrm{W}$, and an altitude of $512 \mathrm{~m}$.

\section{Local climate}

The climate is characterized as humid subtropical Cwa, according to Köppen classification, with hot and rainy summer and cold and dry winter, with temperatures in the hottest month above $22^{\circ} \mathrm{C}$ and the coldest month below $18^{\circ} \mathrm{C}$. The annual average rainfall in the region is $1,408 \mathrm{~mm}$, with rainfall concentrated in the period from November to March.

\section{Experimental design and the treatments}

The experiment had a completely randomized design with factorial $2 \times 2 \times 4$ whose factors were: two fields with mechanical harvest (one and three crop cycles), two sampling sites (crop rows and near-row seedbed strips) and four sampled layers of soil $(0.00-0.10,0.10-0.20,0.20-0.30$ and $0.30-0.40 \mathrm{~m}$ ). Each crop cycle is equivalent to six years of cultivation. After each crop cycle the sugarcane plantation was replanted. Mechanical mulching, subsoiling down to $0.45 \mathrm{~m}$ and subsequent harrowing to level the area were done before new planting.

Delimited are two plots with treatments described below: $\mathrm{T}_{1}$ - Área with 5.37 hectares, with six years of cultivation (or cycle) with mechanized harvesting, CTC 20 variety planted in in 2007; $\mathrm{T}_{2}$ - Area with 5.08 hectares, eighteen years of cultivation (or three cycles) with mechanized harvesting, variety RB 855453 planted in 1995. In both treatments sugarcane was harvested without burning with mechanized cutting with the harvester CASE A8800, accompanied by transshipment.

In each treatment fifteen mini trenches were dug to collect undisturbed samples $(\mathrm{n}=120)$, in layers of $0.00-0.10 ; 0.10$ $0.20 ; 0.20-0.30$ and $0.30-0.40 \mathrm{~m}$. To evaluate the soil physical properties the samples were collected from the planting rows and from the $0.30-\mathrm{m}$ strips of seedbed on each side of the planting row.

\section{The physical soil properties}

\section{Bulk density and resistance to penetration}

The bulk density (BD) was determined on samples with undisturbed structure by volumetric ring method. The samples were collected into rings of $48 \mathrm{~mm}$ diameter and 53 $\mathrm{mm}$ height, with Uhland auger at depths of 0.00-0.05, 0.05$0.10,0.10-0.20$ and $0.20-0.40 \mathrm{~m}$ (Blake and Hartge, 1986). Later, the samples were dried at $105^{\circ} \mathrm{C}$ for 24 hours.

The mechanical resistance to penetration (RP) was determined using an electronic penetrometer with a constant velocity of $1.0 \mathrm{~cm} \mathrm{~min}^{-1}$. It was equipped with a rod and a conical tip $4.0 \mathrm{~mm}$ in diameter and angle of $30^{\circ}$. We considered the limiting values of resistance to penetration as $2.0 ; 2.5 ; 3.0$ and 3.5 MPa (Lapen et al., 2004, Silva et al., 2011). RP data were adjusted for soil density and water content, according to Leo et al. (2006).

In the experimental plots, 120 samples $(15$ mini trenches per plot $\mathrm{x} 2$ plots $\mathrm{x} 2$ sampling sites $\mathrm{x} 4$ layers) were collected to determine the least limiting water range. In the laboratory, the samples were saturated and subjected to stresses of 2, 6, $8,10,33,100,500$ and $1500 \mathrm{kPa}$, in Richards' chambers. After reaching equilibrium, the moist mass and soil resistance to penetration (RP) of each sample were recorded. Next, the 
samples were dried at $105^{\circ} \mathrm{C}$ in an oven until a constant mass was obtained. Finally, the water content and bulk density (BD) (Embrapa, 2011) were calculated.

\section{Macroporosity (Ma), microporosity (Mi) and total porosity (TP)}

The pore distribution by size was determined using samples with undisturbed structure, saturated beforehand for 24 hours using a suction unit to $0.60 \mathrm{~m}$ of water column height, corresponding to the water content of the sample under a tension of $0.006 \mathrm{MPa}$ after saturation. The organic carbon, macroporosity, microporosity and total porosity were obtained according to the methodology of Embrapa (2011).

\section{Water retention curve in the soil}

The water retention curve in the soil was the ratio between the water content and the matric potential of soil density, according to Leon et al. (2006) and Silva et al. (2011). The water content in the aeration porosity were obtained based on bulk density and particle density $\square_{\mathrm{AP}}=[1$ - (BD / PD) - 0.1], considering $0.10 \mathrm{~m}^{3} \mathrm{~m}^{-3}$ as the minimum, necessary for adequate diffusion of oxygen in the soil (Silva et al., 1994).

\section{The least limiting water range}

To determine the least limiting water range (LLWR) we used the method described by Silva et al. (1994, 2011). The soil resistance to penetration and water stresses values were linearized using the natural logarithm. The upper limit of LLWR was $\theta_{\mathrm{FC}}$ and/or $\theta_{\mathrm{AP}}$, while the lower limits were $\theta_{\mathrm{PWP}}$ and/or $\theta_{\mathrm{RP}}$. Soil critical bulk density to root growth (CBD) was considered as the density value at which $L L W R=0$.

\section{Statistical analysis}

The results of analyzes were submitted to ANOVA and Tukey's test at $5 \%$ of probability level for comparison of means with SAS® program. Adjustments of the linearized models were performed using the $\mathrm{SAS}{ }^{\circledR}$ program. The significance of the coefficients of the equations was evaluated by the $t$ test.

\section{Conclusion}

The plot with three cycles of mechanical harvest system showed a higher load carrying capacity and a higher amount of organic carbon in the soil. The area had higher macroporosity and the least limiting water range and lower bulk density and resistance to penetration in the crop rows. The limiting water range (LLWR) was higher in the area with one sugarcane cycle and decreased as the number of mechanical harvest cycles increased. The limiting water range was zero (LLWR $=0$ ) in the areas with $T_{1}$ and $T_{2}$ when the critical bulk density (CBD) ranged between $1.40-1.50 \mathrm{Mg}$ $\mathrm{m}^{-3}$, and $1.24-1.28 \mathrm{Mg} \mathrm{m}^{-3}$, respectively, for a limiting RP between 2.0 and $3.5 \mathrm{Mpa}$. The physical attributes are changed by heavy machinery traffic in the cane fields, but the effects of these changes are minimized when several crop cycles are conducted in the same area.

\section{Acknowledgements}

The authors thank the Federal Institute of Triângulo Mineiro, Campus Uberaba, for the available infrastructure; the National Council for Scientific and Technological
Development $(\mathrm{CNPq})$ for funding the project and granting scholarship.

\section{References}

Araújo FS, Souza ZM, Souza GS, Matsura EE, Barbosa RS (2013) Espacialização do intervalo hídrico ótimo de um Latossolo Vermelho em dois sistemas de colheita de canade-açúcar. Pesq Agr Bras. 48: 651-660.

Blake GR, Hartge KH, Bulk density. In: Klute A (1986) ed., Methods of soil analysis: Physical and mineralogical methods. 2.ed. Madison, Am Soc of Agr, So Sci Soc of Am. p.363-375.

Braunack MV, Arvidsson J, Hakansson I (2006) Effect of harvest traffic position on soil conditions and sugarcane (Saccharum officinarum) response to environmental conditions in Queensland.. Soi Til and Res. 89:103-121.

Camargo LA, Marques Junior J, Pereira G T (2010) Spatial variability of physical attributes of an Alfisol under different hillslope curvatures. R Br Ci Sol. 34: 617- 630.

Campos FS, Alves MC, Souza ZM, Torres JLR (2015) Cropping systems evaluation, fertilization, and effects on technological quality and sugarcane productivity. Afr J Agric Res. 10: 3387-3393.

Cavichioli FA, Furlani CEA, Toledo A, Silva PR, Ribeiro CS (2012) Resistência mecânica do solo à penetração na fileira e entrefileira de cana-de-açúcar em função da mecanização. Eng Na Agri. 20: 46-51.

Chen G, Weil RR, Hill RL (2014) Effects of compaction and cover crops on soil least limiting water range and air permeability. So Til and Res. 136: 61-69.

Conab - acompanhamento da safra brasileira de cana-deaçúcar, v. 2 - Safra 2015/16, n. 2 - Segundo Levantamento, Brasília, agosto/2015. <http://www.conab.gov.br/agosto -2015.pdf > Acesso em: 17042016.

Embrapa - Empresa Brasileira De Pesquisa Agropecuária. Centro Nacional de Pesquisa de Solos. Manual de métodos de análise de solos. 3. Ed. Rio de Janeiro: Ministério da Agricultura e do Abastecimento, 2011, 230 p.

Embrapa - Empresa Brasileira de Pesquisa Agropecuária. Sistema brasileiro de classificação de solos. $3^{\mathrm{a}}$ ed. Brasília, EMBRAPA, 2013, 353p.

Gorucu S, Khalilian A, Han YJ, Dodd RB, Smith BR (2006) An algorithm to determine the optimum tillage depth from soil penetrometer data in coastal plain soils. App Eng in Agric. 22: 625-631.

Guimarães RML, Tormena CA, Blainski E, Fidalski J (2013) Intervalo hídrico ótimo para avaliação da degradação física do solo. R Br Ci Sol. 37: 1512-1521.

Imhoff S, Silva AP, Dias Júnior MS, Tormena CA (2001) Quantificação de pressões críticas para o crescimento das plantas. R Br Ci Sol. 25: 11-18.

Kopi AJ, Douglas JT (1991) A rapid, inexpensive and quantitative procedure for assessing soil structure with respect to cropping. Soi Use Man. 7: 52-56.

Lapen DR, Topp GC, Gregorich EG, Curno WE (2004) Least limiting water range indicators of soil quality and corn production, eastern Ontario, Canada. Soil Til Res. 78: 151170.

Leão TP, Silva AP, Macedo MCM, Imhoff S, Euclides VPB (2006) Least limiting water range: A potential indicator of changes in near-surface soil physical quality after the conversion of Brazilian Savanna into pasture. Soil Til Res. 88: 279-285. 
Materechera SA (2009) Tillage and tractor traffic effects on soil compaction in horticultural fields used for peri-urban agriculture in a semi-arid environment of the North West Province, South Africa. So Til and Res. 103: 11-15.

Mishra AK, Aggarwal P, Bhattacharyya R, Das TK, Sharna AR, Singh R (2015) Least limiting water range for two conservation agriculture cropping systems in India. So Til Res. 150: 43-56.

Moreira WH, Betioli Júnior E, Petean LP, Tormena CA, Alves SJ, Costa MAT, Franco HHS (2012) Atributos físicos de um Latossolo Vermelho distroférrico em sistema de integração lavoura-pecuária. R Br Ci Sol. 36: 389-400.

Mosaddeghi MR, Koolen AJ, Hemmat A, Hajabbasi MA, Lerink P (2007) Comparisons or different procedures of pre-compactation stress determination on weakly structure soils. Jour of Terr. 44: 53-63.

Neves CSVJ, Feller C, Guimarães MF, Medina CC, Tavares Filho J, Fortier M (2003) Soil bulk density and porosity of homogeneous morphological units identified by the cropping profile method in clayey oxisols in Brazil. So Til and Res. 71:109-119.

Roque AAO, Souza ZM, Araújo FS, Silva GRV (2011) Atributos físicos do solo e intervalo hídrico ótimo de um Latossolo Vermelho distrófico sob controle de tráfego agrícola. Ci Rur. 41: 1536-1542.

Safadoust A, Feizee P, Mahboubi AA, Gharabaghi B, Mosaddeghi MR, Ahrens B (2014) Least limiting water range as affected by soil texture and cropping system. Agric Wat Man. 136: 34-41.

Severiano EC, Oliveira GC, Dias Júnior MS, Castro MB, Oliveira LFC, Costa KAP (2009) Compactação de solos cultivados com cana-de-açúcar: II - Quantificação das restrições às funções edáficas do solo em decorrência da compactação prejudicial. Eng Agr. 30: 414-423.

Silva AP, Kay BD (1997) Effect of soil water content variation on the least limiting water range. So Sci Soc Am J. 61: 884-888.
Silva AP, Kay BD, Perfect E (1994) Characterization of the least limiting water range. So Sci Soc Am J. 58: 17751781.

Silva GL, Lima HV, Campanha MM, Gilkes RJ, Oliveira TS (2011) Soil physical quality of Luvisol sunder agroforestry, natural vegetation and conventional crop management systems in the Brazilian semi-arid region. Geod. 167-168: 61-70.

Souza ZM, Prado RM, Paixão ACS, Cesarin LG (2005) Sistemas de colheita e manejo da palhada de cana-deaçúcar. Pesq Agr Bras. 40: 271-278.

Souza HA, Marcelo AV, Centurion JF (2012) Carbono orgânico e agregação de um Latossolo Vermelho com colheita mecanizada de cana-de-açúcar. R Ci Agr. 43: 658663.

Souza GS, Souza ZM, Silva RB, Araújo FS, Barbosa RS, Araújo FS (2014) Effects of traffic control on the soil physical quality and the cultivation of sugarcane. $\mathrm{R} \mathrm{Br} \mathrm{Ci}$ Sol. 38: 135-146.

Souza GS, Souza ZM, Cooper M, Tormena CA (2015) Controlled traffic and soil physical quality of an Oxisol under sugarcane cultivation. Sci Agr. 72: 270-277.

Tormena CA, Silva AP, Libardi P (1998) Caracterização do intervalo hídrico ótimo de um Latossolo Roxo sob plantio direto. $\mathrm{R} \mathrm{Br}$ Ci Sol. 22: 573-581.

Torres JLR, Pereira MG, Cunha MA, Martins ME, Vieira DMS (2013) Physicochemical properties of soil and biomass in sugarcane harvesting systems. Ci Agr. 56: 311318.

Vezzani FM, Mielniczuk J (2011) Agregação e estoque de carbono em argissolo submetido a diferentes práticas de manejo agrícola. R Br Ci Sol. 35: 213-223. 